Article

\title{
Supported Au-Ni nano-alloy catalysts for the chemoselective hydrogenation of nitroarenes
}

\author{
Haisheng Wei a,b, Xing Wei a, Xiaofeng Yang a, Guangzhao Yin c, Aiqin Wang a,*, Xiaoyan Liu a , \\ Yanqiang Huang a, Tao Zhang a,\# \\ a State Key Laboratory of Catalysis, Dalian Institute of Chemical Physics, Chinese Academy of Sciences, Dalian 116023, Liaoning, China \\ b University of Chinese Academy of Sciences, Beijing 100049, China \\ c School of Chemical Engineering, Dalian University of Technology, Dalian 116024, Liaoning, China
}

\section{A R T I C L E I N F O}

Article history:

Received 27 September 2014

Accepted 3 November 2014

Published 20 February 2015

\section{Keywords:}

Gold-nickel

Alloy

Chemoselective hydrogenation

Nitroarenes

\section{A B S T R A C T}

A modified two-step approach was developed for the synthesis of uniform and highly dispersed Au-Ni alloy nanoparticles on a silica support. The supported Au-Ni alloy nanoparticles were investigated for the chemoselective hydrogenation of substituted nitroarenes, which showed a strong synergistic effect between $\mathrm{Au}$ and $\mathrm{Ni}$. The best catalyst was $\mathrm{AuNi}_{3} / \mathrm{SiO}_{2}$ that afforded a selectivity to 3-vinylaniline of $93.0 \%$ at a 3-nitrostyrene conversion of $90.8 \%$ after 70 min under mild conditions. (C) 2015, Dalian Institute of Chemical Physics, Chinese Academy of Sciences. Published by Elsevier B.V. All rights reserved.

\section{Introduction}

The chemoselective hydrogenation of nitroarenes is an environmentally benign and high atomic efficiency approach for the synthesis of functionalized anilines, which are important intermediates for the production of herbicides, pesticides, pigments, drugs, and dyes [1]. Transition metals like Pt, Pd, Ru, and $\mathrm{Ni}$ are typical catalysts in a variety of hydrogenation reactions, but they suffer from a low chemoselectivity in the hydrogenation of substituted nitroarenes, especially when two or more reducing groups are present in one nitroarene molecule [2-4]. On the other hand, IB group metals are usually poor catalysts for hydrogenation reactions, but have recently been shown to be highly chemoselective for the hydrogenation of various substituted nitroarenes [4-9]. Corma et al. [4] reported in 2006 that $\mathrm{Au} / \mathrm{TiO}_{2}$ and $\mathrm{Au} / \mathrm{Fe}_{2} \mathrm{O}_{3}$ afforded $>95 \%$ selectivity at high conversion levels in the chemoselective hydrogenation of 3-nitrostyrene and other substituted nitroarenes. Shimizu et al. [9] found that $\mathrm{Au} / \mathrm{Al}_{2} \mathrm{O}_{3}$ with gold particles of $2.5 \mathrm{~nm}$ performed even better than $\mathrm{Au} / \mathrm{TiO}_{2}$ and $\mathrm{Au} / \mathrm{Fe}_{2} \mathrm{O}_{3}$ : the selectivity for 3-vinylaniline attained $99 \%$ at full conversion of 3-nitrostyrene. They attributed the high chemoselectivity to the unique ability of $\mathrm{Au} / \mathrm{Al}_{2} \mathrm{O}_{3}$ to cause $\mathrm{H}_{2}$ dissociation to produce a $\mathrm{H}^{+} / \mathrm{H}^{-}$pair which is preferentially transferred to the polar bonds in the nitro group. In addition to the support effect, the structure and morphology of the catalyst also affects signifi-

\footnotetext{
* Corresponding author. Tel: +86-411-84379348; Fax: +86-411-84685940; E-mail: aqwang@dicp.ac.cn

* Corresponding author. Tel: +86-411-84379015; Fax: +86-411-84691570; E-mail: taozhang@dicp.ac.cn

This work was supported by the National Natural Science Foundation of China $(21176235,21203182,21202163,21303194$, and 21373206) and the Hundred Talents Program of Dalian Institute of Chemical Physics, Chinese Academy of Sciences. 
cantly the chemoselectivity [9-12]. Mitsudome et al. [10] reported that a AgNPs@ $\mathrm{CeO}_{2}$ catalyst with a core-shell structure gave almost complete chemoselectivity for the reduction of nitrostyrenes, and it was far superior to Ag NPs supported on $\mathrm{CeO}_{2}$.

Despite a satisfactory chemoselectivity, neither $\mathrm{Au}$ nor $\mathrm{Ag}$ catalysts have a promising activity. Their activities for chemoselective hydrogenation reactions are one or two magnitudes lower than those of transition metal catalysts due to the intrinsically poor ability of $\mathrm{Au}$ and $\mathrm{Ag}$ for hydrogen activation $[13,14]$. This unacceptably low activity significantly limits the practical application of $\mathrm{Au}$ and Ag catalysts. In order to improve the catalytic activity of supported Au catalysts while maintaining a high chemoselectivity, a bimetallic strategy of adding a suitable amount of a transition metal to $\mathrm{Au}$ was proposed $[13,15-18]$. The synergism between $\mathrm{Au}$ and a second metal has been intensively studied in the last decade with $\mathrm{Au}-\mathrm{Ag}$ [19-22], $\mathrm{Au}-\mathrm{Cu}$ [23,24], Au-Pd [25-27], Au-Pt [13], Au-Co [28], and $\mathrm{Au}-\mathrm{Ni}$ [29]. However, only a few catalysts gave a chemoselective hydrogenation of nitroarenes. Serna et al. [13] reported that the addition of only $100 \mathrm{ppm}$ Pt to a $1.5 \% \mathrm{Au} / \mathrm{TiO}_{2}$ catalyst resulted in a 20 -fold increase in activity while preserving the high chemoselectivity in the hydrogenation of 3-nitrostyrene to 3-vinylaniline. A similar synergistic effect between $\mathrm{Pt}$ and $\mathrm{Au}$ was also reported for a Pt-on-Au nanostructure in the chemoselective hydrogenation of cinnamaldehyde [30]. For the Au-Pd bimetallic catalyst system, an increase of up to a factor of 3 in activity was observed for the selective hydrogenation of $p$-chloronitrobenzene to $p$-chloroaniline [16] when $\mathrm{Au} / \mathrm{Pd}$ was $>20$. These examples demonstrated the potential of $\mathrm{Au}$ bimetallic catalysts in the chemoselective hydrogenation reactions.

Here, we report the catalytic performance of silica-supported $\mathrm{Au}-\mathrm{Ni}$ alloy nanoparticles in the chemoselective hydrogennation of a variety of substituted nitroaromatics. Compared with the previously reported $\mathrm{Au}-\mathrm{Pt}$ and $\mathrm{Au}-\mathrm{Pd}$ systems, $\mathrm{Au}-\mathrm{Ni}$ catalysts possess the advantage of low cost and is thereby more competitive for practical applications. However, the miscibility gap between $\mathrm{Au}$ and $\mathrm{Ni}$ is a significant challenge in the preparation of homogeneous Au-Ni nanoalloy catalysts [31]. In the present work, we used a modified two-step method in which preformed $\mathrm{Au}$ nanoparticles induced the preferential deposition of $\mathrm{Ni}$ on the Au surface with the assistance of the mild reducing agent, tert-butylamine borane. The resulting Au@Ni core-shell structure was then transformed into a Au-Ni alloy nanophase by reduction in $\mathrm{H}_{2}$ at elevated temperatures, which was shown by X-ray diffraction (XRD), transmission electron microscopy (TEM), and extended X-ray adsorption fine structure (EXAFS) characterization. The Au-Ni nanoalloy catalysts exhibited excellent activity and selectivity in the chemoselective hydrogenation of substituted nitroarenes to the corresponding anilines.

\section{Experimental}

\subsection{Preparation of the Catalysts}

A monometallic $\mathrm{Au} / \mathrm{SiO}_{2}$ catalyst was prepared by the met- hod in our previous report [19]. On a commercial silica support (Qingdao Ocean Chemical Plant, $S_{\mathrm{BET}}=467 \mathrm{~m}^{2} / \mathrm{g}$ ) was grafted 3-aminopropyltriethoxysilane (APTES, 99\%, Acros Organics) by refluxing in ethanol at $80^{\circ} \mathrm{C}$ for $24 \mathrm{~h}$, followed with washing by ethanol and drying in air. The resulting material was denoted as $\mathrm{SiO}_{2}$-APTES. To prepare the Au-Ni bimetallic alloy catalysts, $1 \mathrm{~g}$ of $\mathrm{SiO}_{2}$-APTES was added into $20 \mathrm{~mL} \mathrm{HAuCl}_{4}$ solution (0.01 mol/L) and stirred for $30 \mathrm{~min}$. After filtration and washing with water, the recovered solid was dispersed in $10 \mathrm{~mL}$ water, and $10 \mathrm{~mL} \mathrm{NaBH}_{4}$ solution ( $\left.0.2 \mathrm{~mol} / \mathrm{L}\right)$ was added dropwise under vigorous stirring for the reduction of $\mathrm{AuCl}_{4}^{-}$. After stirring for $15 \mathrm{~min}$, the solid was recovered by filtration and thoroughly washed with water to obtain $4.6 \mathrm{wt} \% \mathrm{Au} / \mathrm{SiO}_{2}$.

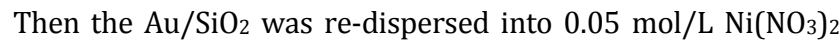
solution with a defined $\mathrm{Au} / \mathrm{Ni}$ ratio, followed by the addition of $0.1 \mathrm{~mol} / \mathrm{L}$ tert-butylamine borane solution to reduce $\mathrm{Ni}^{2+}$. After filtration, washing with water, and drying at $80{ }^{\circ} \mathrm{C}$ for $12 \mathrm{~h}$, the solid was calcined at $500{ }^{\circ} \mathrm{C}$ in air for $6 \mathrm{~h}$ and reduced at $550{ }^{\circ} \mathrm{C}$ in $\mathrm{H}_{2}$ for $1 \mathrm{~h}$ to obtain the $\mathrm{AuNi}_{x} / \mathrm{SiO}_{2}$-cal and $\mathrm{AuNi}_{x} / \mathrm{SiO}_{2}$ cal-red catalysts, respectively ( $x$ refers to the atomic ratio of $\mathrm{Au}$ to $\mathrm{Ni}$ ). For comparison, a $\mathrm{Ni} / \mathrm{SiO}_{2}$ catalyst was prepared by incipient wetness impregnation of the $\mathrm{SiO}_{2}$ support with a $\mathrm{Ni}\left(\mathrm{NO}_{3}\right)_{2}$ solution, followed by the same calcination and reduction treatment as that for the $\mathrm{Au}-\mathrm{Ni} / \mathrm{SiO}_{2}$ catalysts.

\subsection{Reaction tests}

The catalytic testing for the chemoselective hydrogenation of nitroarenes was conducted in an autoclave equipped with a pressure gauge, magnetic stirring system, and water bath. A mixture of nitroarene substrate, solvent, and an internal standard of $o$-xylene with a total volume of $5 \mathrm{~mL}$ was put into the autoclave. Then, the autoclave was flushed with $10^{3} \mathrm{kPa}$ hydrogen 5 times. After sealing, the autoclave was charged with $\mathrm{H}_{2}$ to $300 \mathrm{kPa}$, then heated to $50{ }^{\circ} \mathrm{C}$ in a water bath with stirring to initiate the reaction. After reaction, the product was analyzed by GC-MS.

\subsection{Characterization}

The $\mathrm{Au}$ and Ni loadings were measured with an inductively coupled plasma spectrometer (ICP-AES) on an IRIS Intrepid II XSP instrument (Thermo Electron Corp.). XRD analysis was determined on a PANalytical $X^{\prime}$ pert diffractometer equipped with a $\mathrm{Cu} K_{\alpha}$ radiation source operated at $40 \mathrm{kV}$ and $40 \mathrm{~mA}$. Temperature-programmed desorption of $\mathrm{H}_{2}$ ( $\mathrm{H}_{2}$-TPD) was performed on an Auto Chem II 2920 automatic catalyst characterization system. TEM was carried out using a Tecnai G2 Spirit (FEI) microscope operating at $200 \mathrm{kV}$. High resolution transmission electron microscopy (HRTEM) was conducted with a Tecnai G2 F30S-Twin (FEI) microscope operating at $300 \mathrm{kV}$. The chemical composition of individual particles were measured by energy dispersive X-ray spectroscopy (EDS) on a Tecnai G2 F30S-Twin (FEI) electron microscope. X-ray absorption near edge structure (XANES) and EXAFS spectra at the Au LIII edge and Ni K edge were recorded at beamline 14W of Shanghai Synchrotron Radiation Facility, Shanghai, China. 


\section{Results and discussion}

\subsection{Formation of Au-Ni alloy nanoparticles}

It is a challenging task to form a homogeneous $\mathrm{Au}-\mathrm{Ni}$ alloy due to the large difference in the reduction potential and immiscibility of the two metals at low temperature [31-33]. In our earlier work, we developed a two-step method for the preparation of $\mathrm{Au}$ alloy nanoparticles on a silica support including Au-Ag [19-22], Au-Cu [23,24] and Au-Pd [27], in which $\mathrm{NaBH}_{4}$ was used as the reducing agent in both reduction steps. However, a similar procedure failed in the preparation of $\mathrm{Au}-\mathrm{Ni}$ alloy nanoparticles because $\mathrm{Ni}$ nanoparticles were preferentially formed in the solution rather than on the preformed gold particle surface. Motivated by the noble metal induced reduction (NMIR) method developed by Li and coworkers [34], we modified the two-step method by using a weak reducing agent, tert-butylamine borane, in the second step, which allowed the preferential deposition of $\mathrm{Ni}$ nanoparticles on the gold surface based on the NMIR mechanism. The preparation procedure is illustrated in Fig. 1. The following calcination and reduction treatments were to remove APTES and to promote the formation of a homogeneous Au-Ni alloy phase [19].

Fig. 2(a) presents the XRD patterns of the catalyst samples with different $\mathrm{Au} / \mathrm{Ni}$ ratios. The monometallic $\mathrm{Au} / \mathrm{SiO}_{2}$ sample presented four broad peaks at $2 \theta=38.4^{\circ}, 44.2^{\circ}, 65.1^{\circ}$, and $77.8^{\circ}$ which were assigned to the reflections of the (111), (200), (220), and (311) lattice planes of $\mathrm{Au}$, respectively. The broad peaks indicated the very small size of the Au particles. Using the Scherrer equation with the $\mathrm{Au}(111)$ peak, the average particle size of gold was calculated to be $3.3 \mathrm{~nm}$. For the other three $\mathrm{Au}-\mathrm{Ni}_{x} / \mathrm{SiO}_{2}$-cal-red samples, the reflection peaks were broader than that of the monometallic $\mathrm{Au}$, indicating that the presence of a second metal $\mathrm{Ni}$ suppressed the sintering of the particles during high temperature calcination and reduction. This trend was in agreement with the $\mathrm{Au}-\mathrm{Ag}$ [19-22] and $\mathrm{Au}-\mathrm{Cu}$ $[23,24]$ systems. More interestingly, the reflection peaks of the $\mathrm{Au}-\mathrm{Ni}$ bimetallic samples were shifted to larger degree with an increase in $\mathrm{Ni}$ content, as highlighted in the narrow range XRD patterns (Fig. 2(b)). This provided strong evidence for the formation of the Au-Ni alloy phase. It was also noted that there was no peak assignable to the metallic Ni phase, even for the $\mathrm{Ni}$-rich $\mathrm{AuNi}_{3}$ sample. However, the absence of a monometallic $\mathrm{Ni}$ phase in the XRD pattern does not mean that all the Ni species were in the Ni-Au alloy phase because they could exist as highly dispersed Ni that cannot be detected by XRD.

The TEM images in Fig. 3 provided more details of the particle size distribution. The metal particles in all the samples were
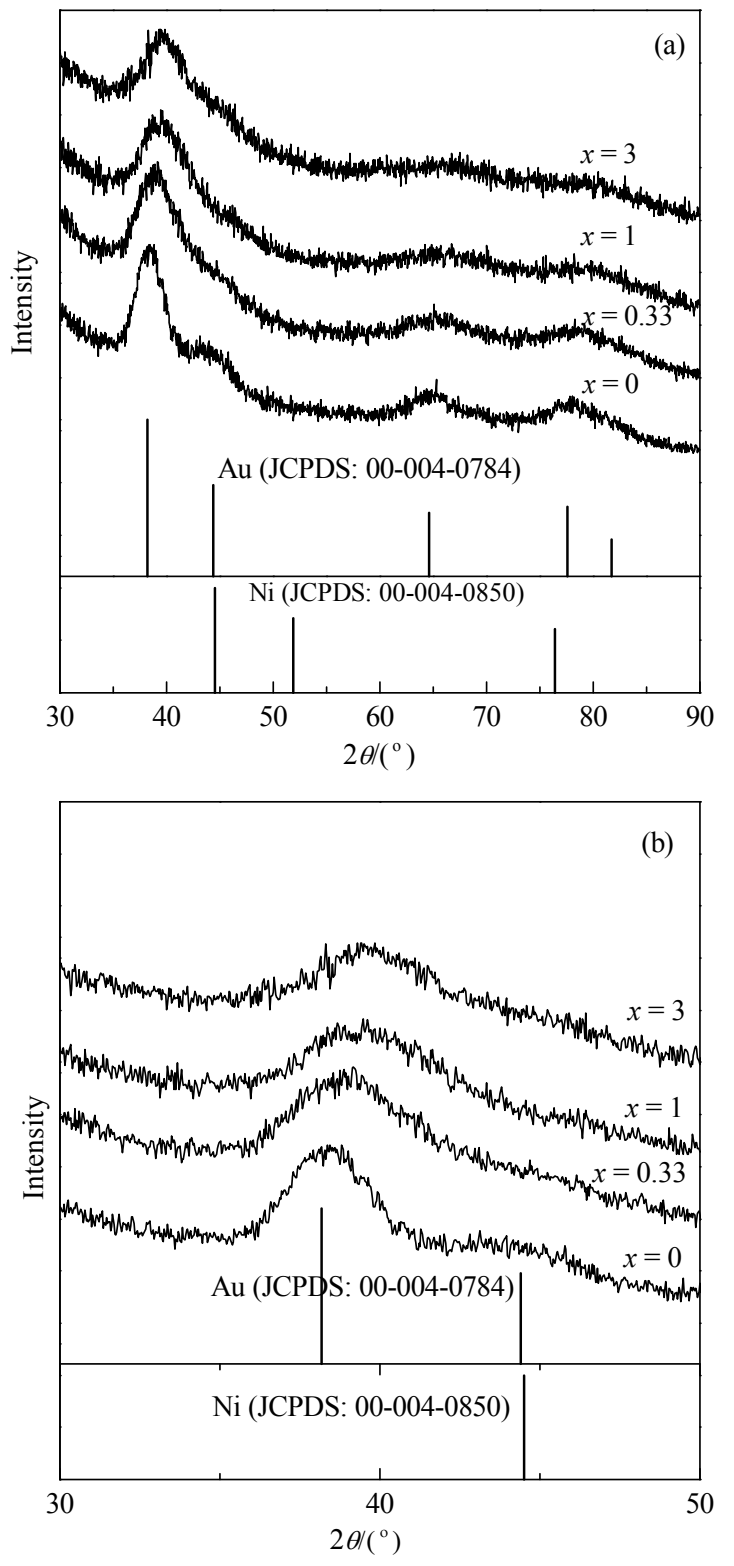

Fig. 2. XRD patterns in a wide range (a) and in $2 \theta=30^{\circ}-50^{\circ}$ (b) of the $\mathrm{AuNi}_{x} / \mathrm{SiO}_{2}$-cal-red catalysts.

uniformly dispersed on the silica support. No very big particles were observed in the different regions of the samples. The histograms in Fig. 4 showed that the average particle size of $\mathrm{Au}$, $\mathrm{AuNi}_{0.33}, \mathrm{AuNi}_{1}$, and $\mathrm{AuNi}_{3}$ were 3.69, 3.44, 3.28 and $3.41 \mathrm{~nm}$, respectively, which was basically in agreement with that estimated from the XRD data. EDS analysis of individual particles

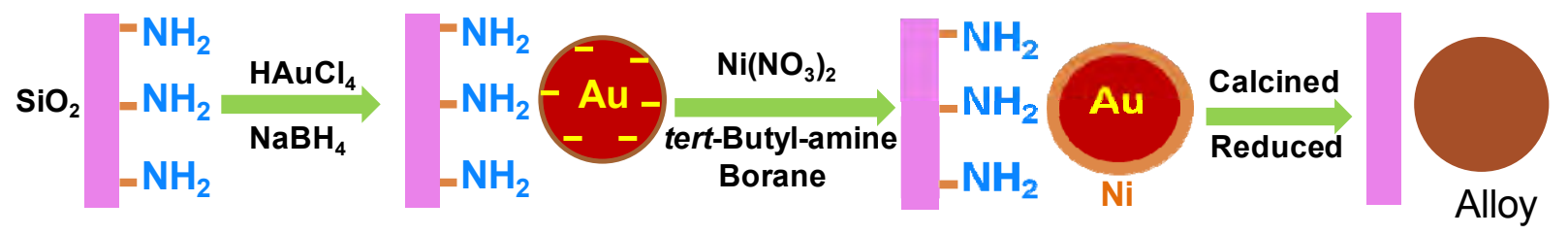

Fig. 1. Schematic of the procedure for the synthesis of $\mathrm{SiO}_{2}$-supported $\mathrm{Au}-\mathrm{Ni}$ alloy nanoparticles. 

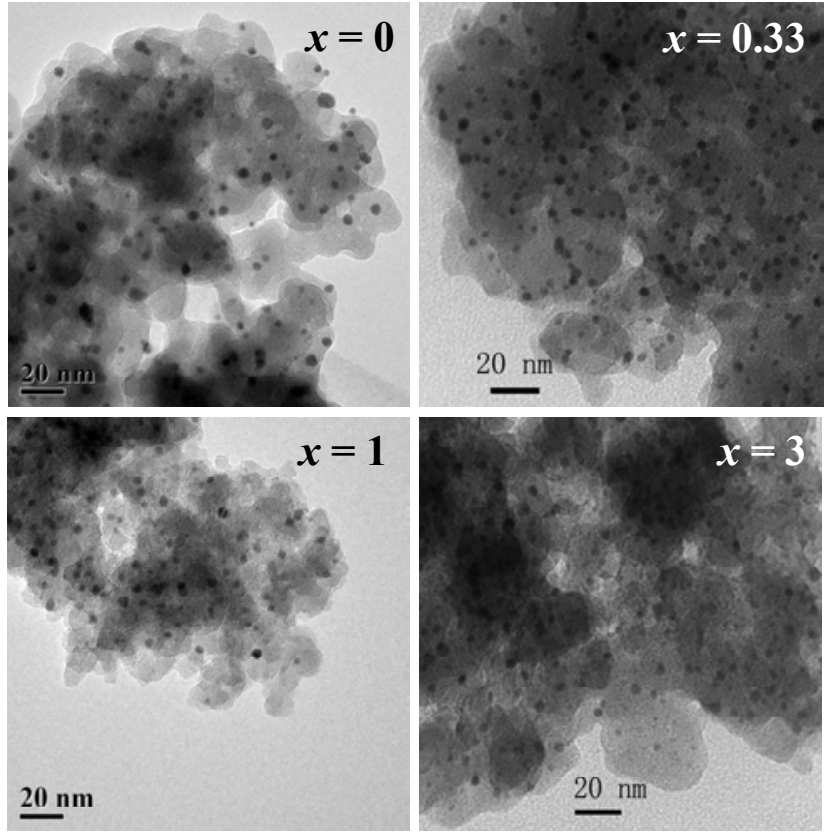

Fig. 3. TEM images of the $\mathrm{AuNi}_{x} / \mathrm{SiO}_{2}$-cal-red catalysts.

revealed that the chemical composition $(\mathrm{Au} / \mathrm{Ni}$ ratio) differed from one particle to another although most particles contained both $\mathrm{Ni}$ and $\mathrm{Au}$ (Fig. 5). Heterogeneity in composition is ubiquitous for bimetallic particles [35-37], which in turn affects the catalytic performance.

EXAFS is a powerful technique for identifying the formation of an alloy phase [38,39]. Hence, we performed in situ EXAFS on the $\mathrm{AuNi}_{3} / \mathrm{SiO}_{2}$ sample. To follow the formation of the $\mathrm{Au}-\mathrm{Ni}$
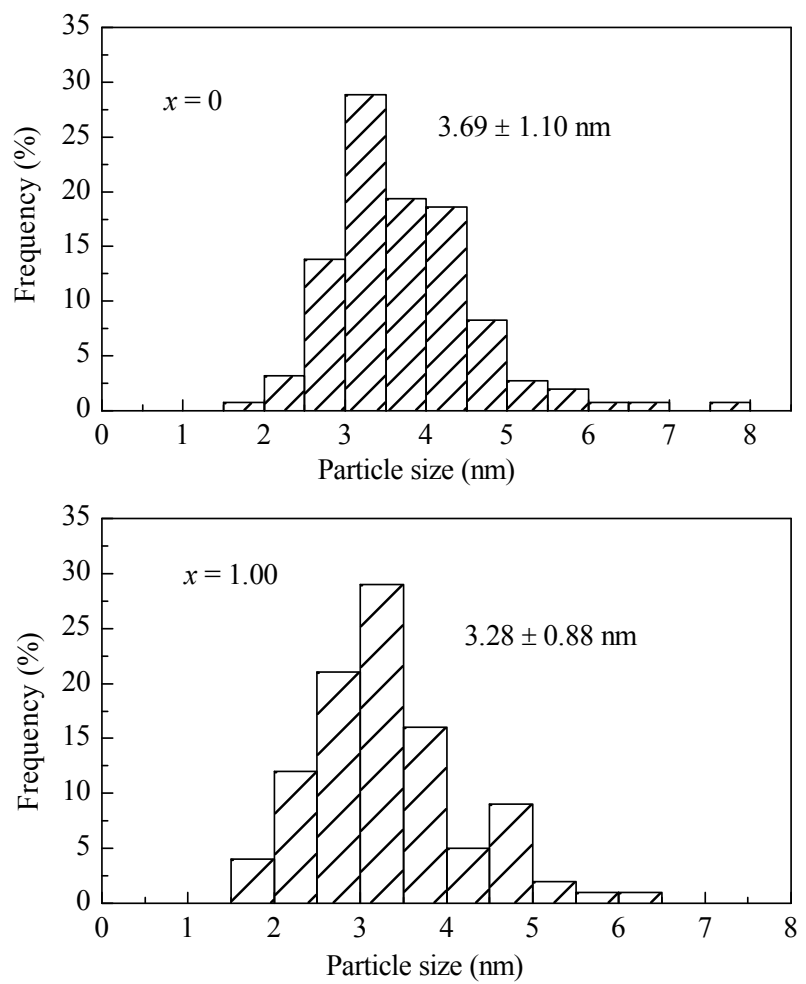

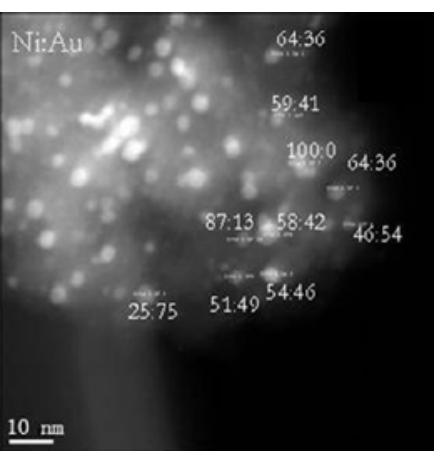

Fig. 5. EDS analysis of individual particles of the $\mathrm{AuNi}_{3} / \mathrm{SiO}_{2}$-cal-red catalyst.

alloy phase, both the calcined and calcined-reduced samples were characterized. The results are shown in Table 1 . For the calcined sample, there were $\mathrm{Au}-\mathrm{Au}$ and $\mathrm{Au}-\mathrm{Ni}$ contributions in the $\mathrm{Au}$ LIII edge, with the coordination numbers (CNs) of 9.2 and 0.4 , respectively, indicating that only a very small fraction of the Ni bonded with $\mathrm{Au}$, while most of the Ni were on the surface of $\mathrm{Au}$ particles or existed as a separate monometallic phase. The same conclusion was reached from the result of the $\mathrm{Ni} \mathrm{K}$ edge. There were three neighboring shells to $\mathrm{Ni}$, which were $\mathrm{Ni}-\mathrm{Au}, \mathrm{Ni}-\mathrm{Ni}$ and $\mathrm{Ni}-\mathrm{O}$ with $\mathrm{CN}$ of $0.5,9.4$, and 4.9 , respectively, in the $\mathrm{AuNi}_{3}$-cal sample. From these results, we concluded that most of the Ni species were $\mathrm{NiO}$ on the surface of the Auparticles as a consequence of the high temperature calcination. After reduction in $\mathrm{H}_{2}$ at $550{ }^{\circ} \mathrm{C}$, the $\mathrm{Au} @ \mathrm{NiO}$ hetero-structure changed greatly. At the Au LiII edge, the CN of the $\mathrm{Au}-\mathrm{Au}$ shell decreased from 9.2 to 5.0 , while the $\mathrm{CN}$ of the $\mathrm{Au}-\mathrm{Ni}$
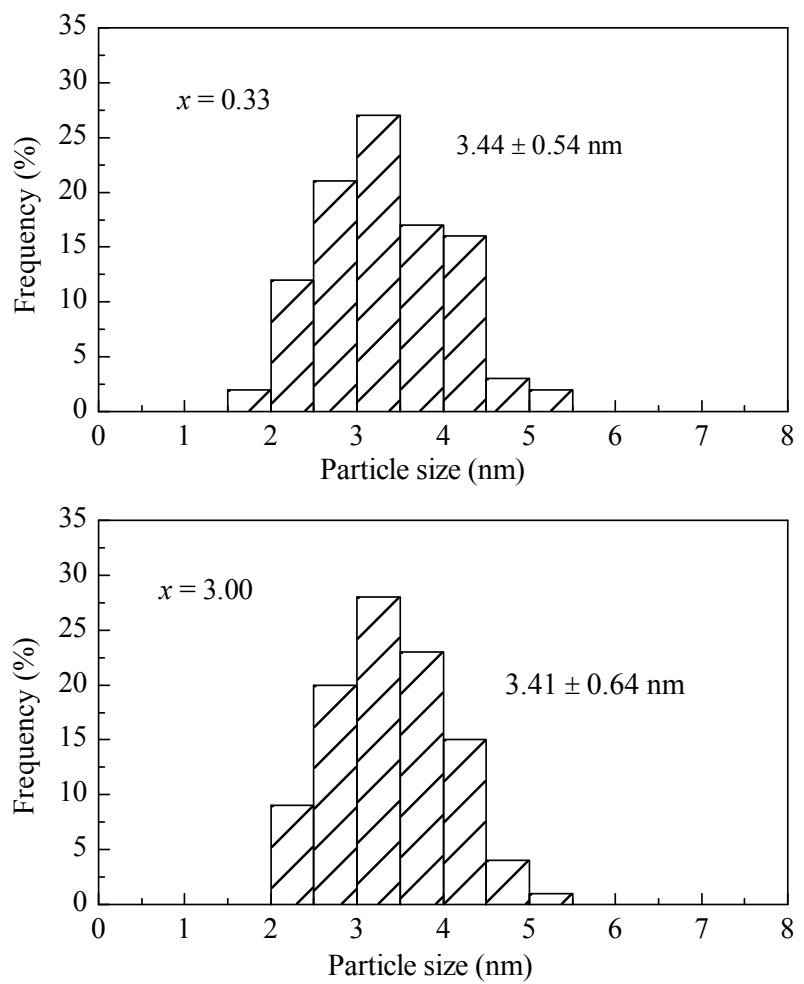

Fig. 4. Particle size distributions of the $\mathrm{AuNi}_{x} / \mathrm{SiO}_{2}$-cal-red catalysts. 
Table 1

EXAFS results of the $\mathrm{AuNi}_{3} / \mathrm{SiO}_{2}$ catalysts after calcination and reduction.

\begin{tabular}{|c|c|c|c|c|c|c|}
\hline Edge \&data fitting range & Sample & Shell & $\mathrm{CN}$ & $R(\AA)$ & $\sigma^{2}\left(\AA^{2}\right)$ & $R$-factor \\
\hline \multirow[t]{5}{*}{ Au L LII edge } & Au foil & $\mathrm{Au}-\mathrm{Au}$ & 12.0 & 2.86 & 0.007 & 0.0009 \\
\hline & $\mathrm{AuNi}_{3} / \mathrm{SiO}_{2}$-cal & $\mathrm{Au}-\mathrm{Au}$ & 9.2 & 2.83 & 0.008 & 0.0026 \\
\hline & & $\mathrm{Au}-\mathrm{Ni}$ & 0.4 & 2.69 & 0.006 & \\
\hline & $\mathrm{AuNi}_{3} / \mathrm{SiO}_{2}$-cal-red & $\mathrm{Au}-\mathrm{Au}$ & 5.0 & 2.78 & 0.006 & 0.0017 \\
\hline & & $\mathrm{Au}-\mathrm{Ni}$ & 3.4 & 2.62 & 0.011 & \\
\hline \multirow[t]{10}{*}{ Ni K edge } & $\mathrm{Ni}$ foil & $\mathrm{Ni}-\mathrm{Ni}$ & 12.0 & 2.48 & 0.005 & 0.0004 \\
\hline & $\mathrm{NiO}$ & $\mathrm{Ni}-\mathrm{O}$ & 6.0 & 2.06 & 0.006 & 0.0016 \\
\hline & & $\mathrm{Ni}-\mathrm{Ni}$ & 12.0 & 2.95 & 0.006 & \\
\hline & $\mathrm{AuNi}_{3} / \mathrm{SiO}_{2}$-cal & $\mathrm{Ni}-\mathrm{Au}$ & 0.5 & 2.69 & 0.001 & 0.0002 \\
\hline & & $\mathrm{Ni}-\mathrm{Ni}$ & 9.4 & 2.99 & 0.014 & \\
\hline & & $\mathrm{Ni}-\mathrm{O}$ & 4.9 & 2.06 & 0.007 & \\
\hline & $\mathrm{AuNi}_{3} / \mathrm{SiO}_{2}$-cal-red & $\mathrm{Ni}-\mathrm{Au}$ & 4.3 & 2.62 & 0.008 & 0.0017 \\
\hline & & $\mathrm{Ni}-\mathrm{Ni}$ & 2.3 & 2.48 & 0.004 & \\
\hline & & $\mathrm{Ni}-\mathrm{O}$ & 2.7 & 2.06 & 0.007 & \\
\hline & & $\mathrm{Ni}-\mathrm{Ni}$ & 5.8 & 3.03 & 0.013 & \\
\hline
\end{tabular}

$\mathrm{CN}$, coordination number of the absorber-backscatterer pair. $R$, the average absorber-backscatterer distance. $\sigma^{2}$, the Debye-Waller factor. The accuracy of the above parameters were estimated as $\mathrm{CN}, \pm 20 \% ; R, \pm 1 \% ; \sigma^{2}, \pm 20 \% ; \Delta E_{0}, \pm 20 \%$. $\Delta k$ and $\Delta R$ are the data range used for data fitting in $k$ space and $R$ space, respectively. For Au LiII edge: $\Delta k: 3.4-12.2 \AA^{-1}, \Delta R: 1.6-3.3 \AA$; For Ni K edge: $\Delta k: 3.3-13.1 \AA^{-1}, \Delta R: 1.3-3.0 \AA$.

shell increased from 0.4 to 3.4 , which was indicative of much more alloying. In agreement with this, the Ni-O coordination number showed a clear decrease after reduction. As a consequence, the $\mathrm{CN}$ of $\mathrm{Ni}-\mathrm{Au}$ and $\mathrm{Ni}-\mathrm{Ni}$ at a distance of $2.48 \AA$ (characteristic of the metal bond of $\mathrm{Ni}$ ) was much increased. The presence of the $\mathrm{Ni}-\mathrm{O}$ contribution after reduction implied that a small fraction of Ni strongly interacted with the silica support to from nickel silicate which cannot be reduced. However, this does not contribute to the catalytic activity in the hydrogenation reactions. The same change was reported earlier in the $\mathrm{Au}-\mathrm{Cu}$ bimetallic system [40].

To summarize, EXAFS results demonstrated that a significant fraction of $\mathrm{Ni}$ was alloyed with $\mathrm{Au}$ in the $\mathrm{AuNi}_{3}$ sample. This alloy phase is expected to show a synergistic effect in hydrogenation reactions.

\subsection{Synergistic effect in the chemoselective hydrogenation of nitroarenes}

To evaluate the catalytic performance of the different Au-Ni catalysts in the chemoselective hydrogenation of nitroarenes, we first studied the chemoselective hydrogenation of 3 -nitrostyrene as it is the most demanding reaction owing to the presence of the $-\mathrm{NO}_{2}$ and $-\mathrm{C}=\mathrm{C}$ groups in one molecule [2]. The reaction was conducted under mild conditions, reaction temperature of $50{ }^{\circ} \mathrm{C}$ and $\mathrm{H}_{2}$ pressure of $300 \mathrm{kPa}$. Table 2 shows the results obtained with the $\mathrm{Au}-\mathrm{Ni}_{x} / \mathrm{SiO}_{2}$ catalysts with various $\mathrm{Au} / \mathrm{Ni}$ ratios. The monometallic $\mathrm{Au} / \mathrm{SiO}_{2}$ catalyst afforded a moderate activity and excellent selectivity to 3-vinylaniline. The conversion and selectivity reached $79.3 \%$ and $99.6 \%$ after $8 \mathrm{~h}$ reaction, respectively. In comparison to $\mathrm{Au} / \mathrm{SiO}_{2}$, the $4.11 \% \mathrm{Ni} / \mathrm{SiO}_{2}$ catalyst was more active but less selective. The conversion and selectivity reached $93.3 \%$ and $78.7 \%$ after $108 \mathrm{~min}$ reaction, respectively. Similar to $4.11 \% \mathrm{Ni} / \mathrm{SiO}_{2}$, commercial Raney $\mathrm{Ni}$ also gave poor selectivity. On the other hand, the $\mathrm{Au}-\mathrm{Ni}_{x} / \mathrm{SiO}_{2}$ bimetallic catalysts gave both high activity and selectivity, demonstrating a strong syn- ergistic effect between the two metals. In particular, with an increase of Ni content in the $\mathrm{Au}-\mathrm{Ni}$ bimetallic catalysts, the activity increased remarkably while the selectivity remained above $90 \%$ at high conversions, implying that Ni contributed mainly to the improvement of the activity while Au preserved the high chemoselectivity. $\mathrm{AuNi}_{3} / \mathrm{SiO}_{2}$ showed the best performance. The conversion and selectivity were $90.8 \%$ and $93.0 \%$ after a reaction time of only $70 \mathrm{~min}$. For a better comparison, we also tested a standard $\mathrm{Au} / \mathrm{TiO}_{2}$ catalyst under identical reaction conditions and with the same $\mathrm{Au} /$ substrate ratio. In agreement with the literature [9], the $\mathrm{Au} / \mathrm{TiO}_{2}$ catalyst afforded a much better performance than $\mathrm{Au} / \mathrm{SiO}_{2}$ : it took $180 \mathrm{~min}$ to obtain $99.6 \%$ conversion and $99.1 \%$ selectivity. Obviously, the redox property of the $\mathrm{TiO}_{2}$ support played an important role in this reaction. In comparison to $\mathrm{Au} / \mathrm{TiO}_{2}$, our $\mathrm{AuNi}_{3} / \mathrm{SiO}_{2}$ catalyst was more active but a little less selective. It can be envisioned that if it was supported on a redox support such as $\mathrm{TiO}_{2}$ or $\mathrm{Fe}_{2} \mathrm{O}_{3}$, the $\mathrm{Au}-\mathrm{Ni}$ bimetallic catalyst could give a better performance than its counterpart on the $\mathrm{SiO}_{2}$ support.

\section{Table 2}

Chemoselective hydrogenation of 3-nitrostyrene over different catalysts.

\begin{tabular}{|c|c|c|c|c|}
\hline Catalyst & $\begin{array}{l}\text { Time } \\
\text { (min) }\end{array}$ & $\begin{array}{c}\text { Conversion } \\
(\%)\end{array}$ & $\begin{array}{c}\text { Selectivity } \\
(\%)\end{array}$ & $\begin{array}{l}\mathrm{TOF}^{\mathrm{a}} \\
\left(\mathrm{h}^{-1}\right)\end{array}$ \\
\hline$\overline{\mathrm{Au} / \mathrm{SiO}_{2}}$ & 480 & 79.3 & 99.6 & 5.5 \\
\hline $\mathrm{AuNi}_{0.33} / \mathrm{SiO}_{2}$ & 310 & 90.5 & 96.4 & 19.9 \\
\hline $\mathrm{AuNi}_{1} / \mathrm{SiO}_{2}$ & 160 & 92.5 & 92.1 & 21.9 \\
\hline $\mathrm{AuNi}_{3} / \mathrm{SiO}_{2}$ & 70 & 90.8 & 93.0 & 17.9 \\
\hline $4.11 \% \mathrm{Ni} / \mathrm{SiO}_{2}$ & 108 & 93.3 & 78.7 & 25.5 \\
\hline $1.37 \% \mathrm{Ni} / \mathrm{SiO}_{2}$ & 480 & 17.3 & 97.8 & 2.8 \\
\hline $0.46 \% \mathrm{Ni} / \mathrm{SiO}_{2}$ & 960 & 11.2 & 99.2 & 1.3 \\
\hline $\mathrm{Au} / \mathrm{TiO}_{2} \mathrm{~b}$ & 180 & 99.6 & 99.1 & - \\
\hline Raney $\mathrm{Ni}^{\mathrm{c}}$ & 155 & 76.8 & 62.5 & - \\
\hline$\underline{4.11 \% \mathrm{Ni} / \mathrm{SiO}_{2}+\mathrm{Au} / \mathrm{SiO}_{2}}$ & 108 & 92.9 & 80.1 & 一 \\
\hline \multicolumn{5}{|c|}{$\begin{array}{l}\text { Reaction conditions: } T=50{ }^{\circ} \mathrm{C}, P=300 \mathrm{kPa}, 0.1 \mathrm{~g} \text { catalyst, } 0.5 \mathrm{mmol} \\
\text { substrate, toluene as a solvent, } o \text {-xylene as an internal standard. } \\
\text { a Calculated based on the metal dispersions in Table } 3 . \\
\text { b Catalyst amount: } 0.3 \mathrm{~g} \text { for the same } \mathrm{Au} / \mathrm{substrate} \text { ratio as } \mathrm{Au} / \mathrm{SiO}_{2} . \\
{ }^{\mathrm{c}} \text { Catalyst amount: } 15 \mathrm{mg} \text { Raney } \mathrm{Ni}+0.1 \mathrm{~g} \mathrm{SiO}_{2} \text { powder. }\end{array}$} \\
\hline
\end{tabular}


Table 3

Physical and chemical properties of the $\mathrm{AuNi}_{x} / \mathrm{SiO}_{2}$ and $\mathrm{Ni} / \mathrm{SiO}_{2}$ catalysts.

\begin{tabular}{|c|c|c|c|c|c|}
\hline \multirow{2}{*}{ Catalyst } & \multicolumn{2}{|c|}{ Metal loading (wt\%) } & \multirow{2}{*}{$\mathrm{H}_{2}$-uptake $(\mu \mathrm{mol} / \mathrm{g})$} & \multirow{2}{*}{$\operatorname{Dispersion}^{\mathrm{a}}(\%)$} & \multirow{2}{*}{ Particle size ${ }^{b}(\mathrm{~nm})$} \\
\hline & $\mathrm{Au}$ & $\mathrm{Ni}$ & & & \\
\hline $\mathrm{Au} / \mathrm{SiO}_{2}$ & 4.54 & - & - & 27.1 & 3.69 \\
\hline $\mathrm{AuNi}_{3} / \mathrm{SiO}_{2}$ & 4.12 & 3.91 & 15 & 29.3 & 3.41 \\
\hline $\mathrm{AuNi}_{1} / \mathrm{SiO}_{2}$ & 4.73 & 1.37 & 27 & 30.5 & 3.28 \\
\hline $\mathrm{AuNi}_{0.33} / \mathrm{SiO}_{2}$ & 4.70 & 0.37 & 12 & 29.1 & 3.44 \\
\hline $4.11 \% \mathrm{Ni} / \mathrm{SiO}_{2}$ & - & 4.11 & 5 & 11.4 & 8.81 \\
\hline $1.37 \% \mathrm{Ni} / \mathrm{SiO}_{2}$ & - & 1.37 & 3 & 16.3 & 6.13 \\
\hline $0.46 \% \mathrm{Ni} / \mathrm{SiO}_{2}$ & - & 0.46 & 6 & 35.2 & 2.84 \\
\hline
\end{tabular}

a Estimated from $D=1 / d\left(D\right.$ : dispersion; $d$ : average diameter of particles); ${ }^{\mathrm{b}}$ Estimate based on more than 200 particles in TEM images.

To further demonstrate the synergy between $\mathrm{Au}$ and $\mathrm{Ni}$, we performed a control experiment with a mechanical mixture of $\mathrm{Ni} / \mathrm{SiO}_{2}$ and $\mathrm{Au} / \mathrm{SiO}_{2}$ with the same metal contents as $\mathrm{AuNi}_{3} /$ $\mathrm{SiO}_{2}$, which was denoted as $4.11 \% \mathrm{Ni} / \mathrm{SiO}_{2}+\mathrm{Au} / \mathrm{SiO}_{2}$. The result showed that this physical mixture catalyst performed similarly to the monometallic $4.11 \% \mathrm{Ni} / \mathrm{SiO}_{2}$ catalyst, giving a selectivity of $80.2 \%$ at a conversion of $92.9 \%$. Clearly, the improvement of the catalytic performance was due to a synergistic effect between the two metals since it was not a simple additive effect.

Another interesting phenomenon was that all the bimetallic $\mathrm{Au}-\mathrm{Ni}$ catalysts gave higher catalytic activity or selectivity than their monometallic $\mathrm{Ni} / \mathrm{SiO}_{2}$ counterparts at the same $\mathrm{Ni}$ content (e.g., $\mathrm{AuNi} 0.33 / \mathrm{SiO}_{2} \quad$ vs. $0.46 \% \mathrm{Ni} / \mathrm{SiO}_{2}, \quad \mathrm{AuNi}_{1} / \mathrm{SiO}_{2}$ vs. $1.37 \% \mathrm{Ni} / \mathrm{SiO}_{2}, \mathrm{AuNi}_{3} / \mathrm{SiO}_{2}$ vs. $\left.4.11 \% \mathrm{Ni} / \mathrm{SiO}_{2}\right)$. The characterization results of the bimetallic catalysts have revealed that the $\mathrm{Au}-\mathrm{Ni}$ nanoalloy phase was formed in these bimetallic catalysts. Even for the $\mathrm{AuNi}_{3} / \mathrm{SiO}_{2}$ catalyst that has excess $\mathrm{Ni}$, there was still a significant amount of $\mathrm{Ni}$ alloying with $\mathrm{Au}$. The formation of the alloy provided intimate contact between $\mathrm{Au}$ and $\mathrm{Ni}$ atoms, thus both geometric and electronic effects between the two metals occurred easily. $\mathrm{H}_{2}$ chemisorption is able to provide useful information on the synergistic effect between the two metals. Table 3 lists the $\mathrm{H}_{2}$ uptake of the Au-Ni bimetallic catalysts and the monometallic counterpart. Monometallic $\mathrm{Au} / \mathrm{SiO}_{2}$ does not adsorb $\mathrm{H}_{2}$, which is consistent with that $\mathrm{Au}$ is a poor catalyst for hydrogen activation [14]. In contrast, the bimetallic Au-Ni catalysts adsorb $\mathrm{H}_{2}$ well. The $\mathrm{H}_{2}$ uptakes were 15, 27, and 12 $\mu \mathrm{mol} / \mathrm{g}_{\mathrm{Cat}}$ for $\mathrm{AuNi}_{3}, \mathrm{AuNi}_{1}$, and $\mathrm{AuNi}$.33, respectively. These $\mathrm{H}_{2}$ uptake values are remarkably larger than that of their monometallic Ni counterparts. Therefore, the formation of the Au-Ni alloy phase allowed $\mathrm{H}_{2}$ to be activated more easily, thus enhancing the catalytic activity for the chemoselective hydrogenation of nitroarenes. On the other hand, previous studies on the surface science of the $\mathrm{Au}-\mathrm{Ni}$ alloy showed that $\mathrm{Au}$ is enriched on the surface in a $\mathrm{H}_{2}$ atmosphere due to its lower surface energy than $\mathrm{Ni}$ $[29,41]$, which facilitates the preferential adsorption of the nitro group on the Au surface and then the chemoselective hydrogenation of nitroarenes. As $\mathrm{Au}$ does not adsorb $\mathrm{H}_{2}$, the metal dispersion was estimated from the average particle size obtained from TEM, rather than from the hydrogen uptake. The results are listed in Table 3. Then, we calculated the TOF (turnover frequency) for the chemoselective hydrogenation of nitroarenes. The results are shown in Table 2. The TOF of the $\mathrm{AuNi}_{3} / \mathrm{SiO}_{2}$ catalyst was 3 fold higher than that of $\mathrm{Au} / \mathrm{SiO}_{2}$ while preserving the selectivity above $90 \%$. Although the $4.11 \% \mathrm{Ni} / \mathrm{SiO}_{2}$ catalyst afforded an even higher TOF than the $\mathrm{AuNi}_{3} / \mathrm{SiO}_{2}$ catalyst, its selectivity to 3-vinylaniline was significantly lower. For the other two monometallic Ni catalysts, the TOF were one order of magnitude lower than the corresponding Au-Ni alloy counterparts. The promising activity and chemoselectivity of $\mathrm{Au}-\mathrm{Ni}$ bimetallic catalysts can be attributed to the improved $\mathrm{H}_{2}$ activation and preserving of the preferential adsorption of nitro groups on the gold surface due to synergy between $\mathrm{Au}$ and $\mathrm{Ni}$.

Finally, the best performance catalyst $\mathrm{AuNi}_{3} / \mathrm{SiO}_{2}$ catalyst was evaluated for the chemoselective hydrogenation of a variety of nitroarene substrates. As shown in Table 4, nitroarens possessing a $\mathrm{C}=\mathrm{C}$ bond, carbonyl, nitriles, and halogens were all transformed to the corresponding substituted anilines with high chemoselectivity at high conversions, demonstrating the great potential of $\mathrm{Au}-\mathrm{Ni}$ bimetallic catalysts for this type of reaction.

Table 4

Chemoselective hydrogenation of different substituted nitroarenes over $\mathrm{AuNi}_{3} / \mathrm{SiO}_{2}$.

\begin{tabular}{|c|c|c|c|c|c|}
\hline Entry & Substrate & Product & $\begin{array}{l}\text { Time } \\
\text { (min) }\end{array}$ & $\begin{array}{c}\text { Conversion } \\
(\%) \\
\end{array}$ & $\begin{array}{c}\text { Selectivity } \\
(\%)\end{array}$ \\
\hline 1 & & 2 & 70 & 90.8 & 93.0 \\
\hline 2 & & & 105 & 94.8 & 93.1 \\
\hline $3^{*}$ & $\mathrm{NO}_{2}$ & $\mathrm{Nl}$ & 100 & 100 & 96.5 \\
\hline $4^{*}$ & & & 60 & 99.5 & 93.1 \\
\hline $5^{*}$ & & & 66 & 97.1 & 99.3 \\
\hline $6^{*}$ & & & 40 & 97.0 & 97.1 \\
\hline
\end{tabular}

Reaction conditions: $T=50^{\circ} \mathrm{C}, P=300 \mathrm{kPa}, 0.1 \mathrm{~g}$ catalyst, $0.5 \mathrm{mmol}$ substrate, toluene as a solvent, o-xylene as an internal standard.

${ }^{*} 0.2$ g catalyst, $T=50{ }^{\circ} \mathrm{C}, P=300 \mathrm{kPa}$. 


\section{Graphical Abstract}

Chin. J. Catal., 2015, 36: 160-167 doi: 10.1016/S1872-2067(14)60254-0

\section{Supported Au-Ni nano-alloy catalysts for the chemoselective hydrogenation of nitroarenes}

Haisheng Wei, Xing Wei, Xiaofeng Yang, Guangzhao Yin, Aiqin Wang*, Xiaoyan Liu, Yanqiang Huang, Tao Zhang* Dalian Institute of Chemical Physics, Chinese Academy of Sciences; University of Chinese Academy of Sciences; Dalian University of Technology

Supported Au-Ni alloy nanoparticles were highly active and chemoselective for the hydrogenation of substituted nitroarenes due to a synergistic effect between $\mathrm{Au}$ and $\mathrm{Ni}$. The best catalyst was $\mathrm{AuNi}_{3} / \mathrm{SiO}_{2}$.

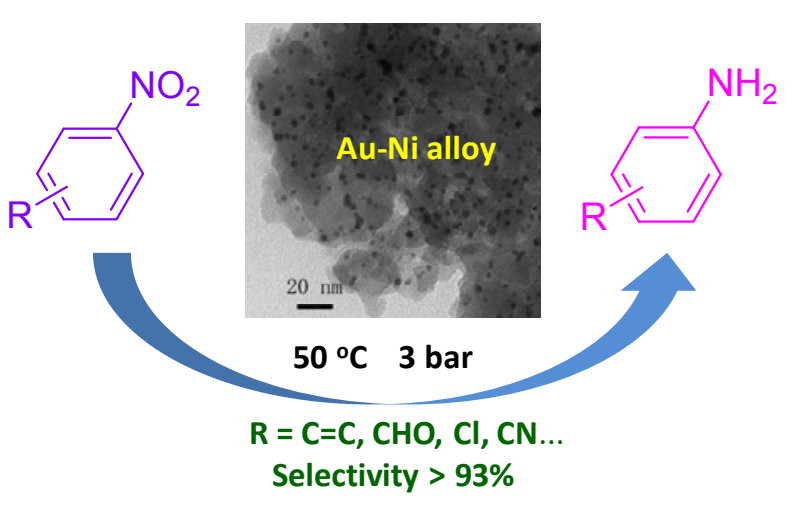

\section{Conclusions}

Silica-supported Au-Ni alloy nanoparticles with different $\mathrm{Au} / \mathrm{Ni}$ ratios were prepared with a modified two-step method in which Au nanoparticles were deposited on an APTES- functionalized silica surface in the first step, and Ni was preferentially deposited on the Au surface in the second step by using a weak reducing agent, tert-butylamine borane. After calcination and reduction, a Au-Ni alloy phase was formed. The Au-Ni alloy nanocatalysts were highly active and chemoselective for the hydrogenation of substituted nitroarenes to the corresponding anilines. The $\mathrm{AuNi}_{3} / \mathrm{SiO}_{2}$ catalyst gave the best performance with a chemoselectivity of $93.0 \%$ at $90.8 \%$ conversion for 3-nitrostyrene hydrogenation. The enhanced activity was attributed to the improved $\mathrm{H}_{2}$ dissociation on the Au-Ni alloy phase.

\section{Acknowledgments}

The authors thank the students and staff at beamline 14W (Shanghai Synchrotron Radiation Facility, Shanghai, China) for their assistance with the EXAFS data collection.

\section{References}

[1] Ono N. The Nitro Group in Organic Synthesis. NewYork: John Wiley \& Sons, 2003

[2] Xu K L, Zhang Y, Chen X R, Huang L, Zhang R, Huang J. Adv Synth Catal, 2011, 353: 1260

[3] Liu H, Li R Y, Zhang M, Li W, Zhang M H, Tao K Y. Chin J Catal (刘皓, 李若愚, 张濛, 李伟, 张明慧, 陶克毅. 催化学报), 2009, 30: 606

[4] Corma A, Serna P. Science, 2006, 313: 332

[5] Chen Y Y, Qiu J S, Wang X K, Xiu J H. J Catal, 2006, 242: 227

[6] Chen Y Y, Wang C, Liu H Y, Qiu J S, Bao X H. Chem Commun, 2005: 5298

[7] Shimizu K I, Miyamoto Y, Satsuma A.J Catal, 2010, 270: 86

[8] He L, Ni J, Sun H, Cao Y. Chin J Catal (何林, 倪吉, 孙浩, 曹勇. 催化 学报), 2009, 30: 958
[9] Shimizu K I, Miyamoto Y, Kawasaki T, Tanji T, Tai Y, Satsuma A.J Phys Chem C, 2009, 113: 17803

[10] Mitsudome T, Mikami Y, Matoba M, Mizugaki T, Jitsukawa K, Kaneda K. Angew Chem Int Ed, 2012, 51: 136

[11] Boronat M, Concepción P, Corma A, González S, Illas F, Serna P. J Am Chem Soc, 2007, 129: 16230

[12] Cárdenas-Lizana F, Gómez-Quero S, Keane M A. ChemSusChem, 2008, 1: 215

[13] Serna P, Concepción P, Corma A. J Catal, 2009, 265: 19

[14] Corma A, Boronat M, González S, Illas F. Chem Commun, 2007: 3371

[15] He D P, Jiao X D, Jiang P, Wang J, Xu B Q. Green Chem, 2012, 14: 111

[16] Cárdenas-Lizana F, Gómez-Quero S, Hugon A, Delannoy L, Louis C, Keane M A. J Catal, 2009, 262: 235

[17] Cárdenas-Lizana F, Gómez-Quero S, Baddeley C J, Keane M A. Appl Catal A, 2010, 387: 155

[18] Wang A Q Liu X Y, Mou C Y, Zhang T. J Catal, 2013, 308: 258

[19] Liu X Y, Wang A Q, Yang X F, Zhang T, Mou C Y, Su D S, Li J. Chem Mater, 2009, 21: 410

[20] Wang A Q, Liu J H, Lin S D, Lin T S, Mou C Y. J Catal, 2005, 233: 186

[21] Wang A Q, Hsieh Y P, Chen Y F, Mou C Y. J Catal, 2006, 237: 197

[22] Wang A Q Chang C M, Mou C Y.J Phys Chem B, 2005, 109: 18860

[23] Liu X Y, Wang A Q, Wang X D, Mou C Y, Zhang T. Chem Commun, 2008: 3187

[24] Li W J, Wang A Q, Liu X Y, Zhang T. Appl Catal A, 2012, 433: 146

[25] Zhang L L, Wang A Q, Miller J T, Liu X Y, Yang X F, Wang W T, Li L, Huang Y Q, Mou C Y, Zhang T. ACS Catal, 2014, 4: 1546

[26] Pei G X, Liu X Y, Wang A Q, Li L, Huang Y Q, Zhang T, Lee J W, Jang B W-L, Mou C Y. New J Chem, 2014, 38: 2043

[27] Wei X, Yang X F, Wang A Q Li L, Liu X Y, Zhang T, Mou C Y, Li J.J Phys Chem C, 2012, 116: 6222

[28] Xu X J, Fu Q, Wei M M, Wu X, Bao X H. Catal Sci Technol, 2014, 4: 3151

[29] Xu X J, Fu Q, Guo X G, Bao X H. ACS Catal, 2013, 3: 1810

[30] Sun K Q, Hong Y C, Zhang G R, Xu B Q. ACS Catal, 2011, 1: 1336

[31] Bienzle M, Oishi T, Sommer F. J Alloys Compd, 1995, 220: 182

[32] Zhou S H, Yin H F, Schwartz V, Wu Z L, Mullins D, Eichhorn B, Overbury S H, Dai S. ChemPhysChem 2008, 9: 2475

[33] Molenbroek A M, Nørskov J K, Clausen B S. J Phys Chem B, 2001, 105: 5450

[34] Wang D S, Li Y D. J Am Chem Soc, 2010, 132: 6280 
[35] Xu J, White T, Li P, He C H, Yu J G, Yuan W K, Han Y F. J Am Chem Soc, 2010, 132: 10398

[36] Russier-Antoine I, Bachelier G, Sablonière V, Duboisset J, Benichou E, Jonin C, Bertorelle F, Brevet P F. Phys Rev B, 2008, 78: 035436

[37] Bulushev D A, Beloshapkin S, Plyusnin P E, Shubin Y V, Bukhtiyarov V I, Korenev S V, Ross J R H.J Catal, 2013, 299: 171

[38] Liu X Y, Wang A Q Li L, Zhang T, Mou C Y, Lee J F. Prog Nat Sci,
2013, 23: 317

[39] Yen C W, Lin M L, Wang A Q, Chen S A, Chen J M, Mou C Y.J Phys Chem C, 2009, 113: 17831

[40] Liu X Y, Wang A Q, Li L, Zhang T, Mou C Y, Lee J F. J Catal, 2011, 278: 288

[41] Jiang H L, Umegaki T, Akita T, Zhang X B, Haruta M, Xu Q. Chem Eur J, 2010, 16: 3132

\section{负载型Au-Ni合金催化剂应用于芳香硝基化合物选择加氢反应 \\ 魏海生 ${ }^{\mathrm{a}, \mathrm{b}}$, 卫 星 ${ }^{\mathrm{a}}$, 杨小峰 ${ }^{\mathrm{a}}$, 银光照 ${ }^{\mathrm{c}}$, 王爱琴 ${ }^{\mathrm{a},}{ }^{*}$, 刘晓艳 ${ }^{\mathrm{a}}$, 黄延强 ${ }^{\mathrm{a}}$, 张 涛, ${ }^{\mathrm{a}, \#}$ a中国科学院大连化学物理研究所, 辽宁大连 116023 \\ ${ }^{\mathrm{b}}$ 中国科学院大学, 北京 100049 \\ ${ }^{\mathrm{c}}$ 大连理工大学化工学院, 辽宁大连 116024}

摘要: 采用改进的两步还原法制备了 $\mathrm{SiO}_{2}$ 负载的 $\mathrm{Au}-\mathrm{Ni}$ 合金催化剂, 催化剂中 $\mathrm{Au}-\mathrm{Ni}$ 纳米颗粒高度分散于 $\mathrm{SiO}_{2}$ 载体表面. $\mathrm{Au}-\mathrm{Ni}$ 合 金催化剂在温和条件下芳香硝基化合物选择加氢反应中表现出比两种单金属催化剂更高的活性和选择性,体现出 $\mathrm{Au}-\mathrm{Ni}$ 之间明显 的协同作用. 其中 $\mathrm{AuNi}_{3} / \mathrm{SiO}_{2}$ 催化剂具有最好的性能, 反应 $70 \mathrm{~min}$, 转化率和选择性分别达到 $90.8 \%$ 和 $93.0 \%$.

关键词: 金-镍; 合金; 选择加氢; 芳香硝基化合物

收稿日期: 2014-09-27. 接受日期: 2014-11-03. 出版日期: 2015-02-20.

*通讯联系人. 电话: (0411)84379348; 传真: (0411)84685940; 电子信箱: aqwang@dicp.ac.cn

通讯联系人. 电话: (0411)84379015; 传真: (0411)84691570; 电子信箱: taozhang@dicp.ac.cn

基金来源：国家自然科学基金(21176235, 21203182, 21202163, 21303194, 21373206); 中国科学院大连化学物理研究所百人计划 基金.

本文的英文电子版由Elsevier出版社在ScienceDirect上出版(http://www.sciencedirect.com/science/journal/18722067). 